\title{
Pathology of Vitamin A Deficiency and its Clinical Significance
}

\author{
By Z. A. LeITNER, 52 Welbeck Street, London, $W$. I
}

Pathology is concerned with the response of living organs or tissues to injury. If the injury is not lethal repair or gradual adaptation follows. Deficiency of a single vitamin rarely occurs naturally but, as a conditioned deficiency, may provoke considerable damage to the living cells (Leitner, 1948). The morphological changes in such a conditioned deficiency may reflect the peculiar biochemical damage caused to one type of cell in one single organ, or to the same type of cell distributed in different tissues; in the latter case, secondary effects such as loss of function and inanition may affect the whole organism.

\section{Tissue changes in vitamin $A$ deficiency}

For lack of space, only certain topics can be considered.

Epithelial tissue. The effects of vitamin A deficiency on the epithelial tissue may be summarized as atrophy of the epithelial layer followed by reparative proliferation of the basal cells with growth and differentiation into a stratified keratinizing epithelium (Wolbach \& Howe, 1925, 1926). These changes occur in man and presumably in all vertebrates, even in the foetus (Wilson \& Warkany, 1947). Mainly affected are epithelia with secretory function, such as the salivary glands, including the tongue and pharynx, the respiratory tract with the trachea and bronchi, the eyes including the cornea, conjunctivas and intra- and extra-orbital glands, the genito-urinary tract with the renal pelvis, ureters and bladder, and the sex glands. In man, the skin also may be involved. Keratinization in the secretory cells may produce severe obstruction in the gland ducts with cystic dilatation and accumulation of debris leading to severe infection of the surrounding tissues (Wolbach \& Bessey, 1942) (Pls. I and 2). On the other hand, epithelial cells with chemical function and capable of division, such as those of the liver, do not show marked atrophy, and do not exhibit keratinizing metaplasia.

After vitamin A administration, each individual epithelium reassumes its normal structure and function, when the keratinized cells have been removed by autolysis and leucocytic infiltration (Wolbach \& Howe, 1933a,b).

Incisur teeth of rodents. In rats and guinea-pigs the enamel organ, which is of epithelial origin, atrophies and undergoes keratinizing metaplasia in vitamin A deficiency. The odontoblasts which are cells of mesenchymal origin are then unable to deposit dentin in the normal way and produce an abnormally thick layer on the labial side, and an abnormally thin one elsewhere. After vitamin A administration regeneration of the enamel organ with resumption of normal dentin formation takes place (Wolbach \& Howe, 1933a, $b ; \mathrm{H}$. Mellanby, 1939). Boyle (1933) described similar changes in a human infant, and hyperplastic keratinized gums have been observed in man (King, 1940).

Skeleton. If vitamin A deficiency is established at a sufficiently early stage, skeletal growth in rats may be retarded in a way involving only the endochondral bone formation. On the other hand, there is an excess of periosteal bone formation, whilst the soft tissues, including nerve tissue, continue to grow until general inanition occurs. The 
degeneration of nerve tissue in vitamin A deficiency was first noticed by Mellanby (193I, 1935). He found later that the experimental dogs became deaf, and proved that the deafness was due mainly to bony overgrowth of the labyrinth and only secondarily to nerve change (Mellanby, 1938). It was further suggested (Mellanby, 1939a, $b$; Wolbach \& Bessey, 1940, 194I) that all nerve lesions due to vitamin A deprivation are caused by bone pressure; thus, overcrowding of the cranial cavity causes multiple herniation of the cerebrum and cerebellum into the dural sinuses; overcrowding of the spinal cord causes herniations of the nerve roots into the intervertebral foramina, and pressure leads to degeneration of the nerve roots, peripheral nerves and various cerebral tracts. Mellanby $(1939 a, b)$ found compression of the optic nerve and signs of raised intrathecal pressure due to thickening of the cranial bones. Subsequently, he demonstrated compression of the olfactory, optic, trigeminal and cochlear nerves and also of the pituitary body in puppies and rabbits (Mellanby, 1941, 1943a,b). After vitamin A administration the changes are to some extent reversible (Mellanby, 1947). Such nerve lesions caused by bone pressure have not yet been recognized as an effect of vitamin A deficiency in man, but are quite common in cattle under field conditions; in calves, for instance, narrowing of the optic foramen constricts the optic nerve, and causes papilloedema and blindness (L. A. Moore, 1939); increased cerebrospinal fluid pressure also (L. A. Moore \& Sykes, 1940) has often been observed.

Nerve tissue. Whether degeneration of nerve tissue occurs as a direct result of vitamin A deficiency has been a controversial issue during the last 20 years (Mellanby, I93 I). Several authors have produced valid evidence of the occurrence of direct nervetissue lesions (Rao, 1940; Irving \& Richards, 1940), and recently further evidence has been presented that bone pressure is not the only explanation. Ducks were maintained on a vitamin A-deficient diet and after from 10 to I 5 days showed muscular weakness, incoordination, ataxia and paralysis. On histological examination, there was sliding of the grey and white matter over one another, with haemorrhage, necrosis, degeneration of nerve cells and tracts, and intermedullary formation of cartilage and bone (Fletcher \& Rigdon, I949). Such changes, especially the finding of cartilage and bone within the nerve substance, cannot easily be related to the mechanical theory, as the makers of these observations point out.

\section{Congenital abnormalities related to vitamin $A$ deficiency}

Results of animal experiments provide convincing evidence that nutritional deficiency in pregnancy may not produce any signs in the mother but that the young may die during the first few days of life. Another important concept is that the frequency of occurrence of a hereditary congenital malformation may be enhanced by dietary deficiency in pregnancy, so that the latent tendency to a congenital trait, only rarely manifest in favourable conditions, may be expressed if the antenatal diet is deficient, especially in vitamin A. The conclusion is a difficult one to apply to man, but it can be reasonably assumed that neonatal mortality and incidence of congenital malformations increase in unfavourable nutritional circumstances.

In the offspring of pigs given a diet deficient in vitamin A, Hale (1933, 1935, 1937) 
found blindness with anophthalmos or microphthalmos, accessory ears, cleft lip and palate, and misplaced kidneys. More systematic investigations by Warkany and his colleagues amplified the results (Warkany \& Schraffenberger, 1944, 1946; Warkany \& Roth, 1948; Warkany, 1948; Wilson \& Barch, 1949). They found that the fertility of rats kept on a vitamin A-poor diet was low; some resorbed their young; the offspring of others were often stillborn or died within a day or two. If they survived, their size was less than normal, and they were oedematous and frequently had subcutaneous haemorrhages. In about $75 \%$, ocular abnormalities were present, such as defective eyelids, a fibrous mass behind the lens in place of the vitreous body, coloboma or eversion of the retina, and rudimentary development of the iris, ciliary body or anterior chamber. Other congenital defects regularly produced were in the development of the lungs and pleural cavity, in the aortic arches and in the interventricular septum; other defects were spongy myocardium, diaphragmatic hernias (Wilson \& Warkany, r949, 1950), undeveloped renal pelvis and ureters, fused and horseshoe kidneys, undescended testes, absence of seminal vesicles and bulbo-urethral glands, and complete lack of vagina (Wilson \& Warkany, 1948). The difficulty of applying the results of these animal experiments to man was pointed out by Jackson \& Kinsey (1946) who confirmed Warkany's work on eye defects. The commonest ocular malformation in rats was a kind of retrolental fibroplasia, a disease which in recent years caused blindness in about $8 \%$ of premature babics under $5 \mathrm{lb}$. in the Lnited States. 'The intake of vitamin A required to produce this malformation in rats had, however, to be less than $16 \%$ of the normal, a degree of deficiency unlikely to occur in pregnant women. In contrast, however, evidence has been presented quite recently of a possible correlation between the incidence of retrolental fibroplasia and the use of large amounts of iron and watermiscible vitamins in man; it is claimed now that large doses of vitamin $\mathrm{E}$ reduce the incidence of this disease (Owens \& Owens, 1949).

Fibrocystic disease of the pancreas. It is of interest to make reference here to two inherited diseases encountered in man, for which some relationship to vitamin A deficiency is claimed. Fibrocystic disease of the pancreas (Andersen, 1938; Blackfan \& May, 1938) was diagnosed, before 1938 , mainly after death, and appears invariably to lead to death before the age of 16 (Parmelee, 1935; Mattheson, 1949). The condition is characterized by steatorrhoea, a low level of vitamin A in the blood, and epithelial changes like keratinizing metaplasia in the lungs and pancreas and occasionally in other organs. Apart from the isolated cases admitted to hospital, usually during the first few days after birth, with the diagnosis of meconium ileus for want of pancreatic digestion (Farber, 1944), the large majority of the infant sufferers perish from recurrent bronchopneumonia. Reviewing the circumstances in twenty families affected by the disease, Andersen \& Hodges (1946) suggested that the condition might be due to an inherited recessive trait, or even to an incomplete dominant (Cockayne,'I 947). Andersen (1949a-c) considers that the condition is of nutritional origin, and she maintains that in cases diagnosed at an early stage dietary therapy, including large doses of vitamin A, prevented the development of chronic respiratory infection. The theory of a nutritional aetiology has been contested recently and the view has been advanced that the vitamin $A$ changes are only of a secondary nature (Bodian, 1950). 
Pityriasis rubra pilaris. Another disease characterized by a low level of vitamin A in the blood and generalized keratinizing metaplasia is pityriasis rubra pilaris which will be discussed later in more detail. The existence of two different forms, a hereditary and an acquired one, has been accepted until recently (Touraine, 1942). After having collected 152 cases from the world literature, the present author was able to demonstrate with the help of Ford that pityriasis rubra pilaris is always inherited, probably as a simple, autosomal, heterozygous condition, without being even partially sex-controlled, and without linkage with the blood group (Leitner, 1947a). The apparently non-familial cases are due to mutation (Leitner \& Ford, 1947; Cockayne, 1950).

Only two patients with pityriasis rubra pilaris have been encountered, in connexion with whom, in spite of thorough search, no other affected member of the family could be traced. One was a man affected first at the age of 63 ; one of his children was in every way normal, but the other, a well-nourished and healthy woman of 30 , had the pathologically low level for vitamin A in the plasma of 44 i.u./100 ml. (Barber \& Leitner, 195I). Skipping of a generation and reduced expressivity of a gene have been occasionally observed in families even with dominant abnormal traits, but microforms of the abnormality or slight deviations from the normal may often be detected only by special examination.

The second patient had syringomyelia as well as pityriasis rubra pilaris (Barber \& Tatz, 1946). The great importance of this case lies in the fact that both conditions were inherited, and that two different systems of ectodermal origin, the skin and the central nervous system, were involved in the same patient (Leitner, 1946).

\section{Clinical significance of vitamin $A$ deficiency}

Confronted with the abundant literature of the past 20 years on the manifold symptoms of vitamin A deficiency, and with the predominantly negative results of the Sheffield experiment on young, healthy conscientious objectors (Hume \& Krebs, 1949), one is hesitant to embark on this chapter. Clinical medicine, however, in contrast with the Sheffield and other experiments (Steffens, Bair \& Sheard 1939), deals with subjects of every age group, and with known or unknown impairments of the organs, who in addition are exposed to a number of conditioning factors (Leitner, 1948). Diseases caused by lack of water-soluble vitamins are easily detectable, but it is much more difficult to relate symptoms and signs to a lack of vitamin A, of which reserves may be stored in the organs for up to 2 years. For this reason the discussion of the clinical aspect should be considered, not so much as a statement of facts, but rather as an assessment of views prevailing at present.

It is quite impossible to deal adequately with the whole clinical significance of vitamin A deficiency in the available space. It may, however, be briefly mentioned that the antagonistic action of vitamin A and thyroxine (Fasold \& Peters, 1933), postulated for many years, has been confirmed (Sadhu, 1948). In two patients suffering from thyrotoxicosis, clinical cure was achieved by daily peroral doses of $200,000-400,000$ i.u. vitamin A after 4-8 weeks (Simkins, 1947). Continental workers have claimed good results in treating several clinical conditions, including pulmonary tuberculosis (Lafontaine, 1948) and hypertension (Bonfils, 1947). 
Relation of vitamin $A$ to the health of the eye. The changes which take place in the eye when the organism is deprived of vitamin A are too well known to need description. The first change causes hemeralopia, and later Bitot's spots, xerophthalmia and keratomalacia appear.

Relation of vitamin A to cutaneous diseases. Keratinizing metaplasia has already been mentioned as the cardinal change in vitamin A deficiency, a view that has been accepted by paediatricians (Blackfan \& Wolbach, I933; Sweet \& K'ang, 1935) and by nearly all workers interested in nutrition. 'There are, however, difficulties in its application to cutaneous diseases in man.

An interesting point is the fact that, even after excessive amounts of vitamin A had been given, it could not be detected by fluorescence microscopy in the epidermis (Cornbleet \& Popper, 1942), or epithelium of mucous membranes, which are considered to be the first sites of vitamin A deficiency (Popper, 194I). Moreover, conservative pathologists still maintain that keratinizing metaplasia is caused only by irritation or chronic inflammation, though Beattie, Dickson \& Drennan (1948) state that metaplasia may result from impairment of nutrition and function.

In experiments on rats, no true keratinizing metaplasia could be produced by irritation or by giving oestrogens, unless the animals were deprived of vitamin $\mathrm{A}$ (McCullough \& Dalldorf, 1937). The opposite was, however, never conclusively proved, namely that the same type of metaplasia cannot be achieved by any other means in adequately fed rats. A varying degree of hyperkeratosis, comparable with that seen in man, the extent of which was inversely related to the amount of vitamin A ingested, was produced in rats by Moult (1943). No conclusive evidence for the experimental production of follicular keratosis in man has, however, been presented as yet, even when the deprivation has been maintained for as long as 25 months (Hume \& Krebs, 1949).

The extensive literature on human skin lesions attributed to vitamin A deficiency has been repeatedly discussed recently (Stannus, 1945; Leitner 1945, 1947a, $b$; Leitner \& Moore, 1946a, $b$; Marrack, 1948). Though we have no knowledge about its mechanism, there seems little doubt that vitamin $A$ is one of the main factors essential for the normal metabolism of the epithelium. Little is understood of its interrelationship with such other factors as the vitamin B complex (Sullivan \& Evans, I945), traumata (Stannus, 1945), or vitamin C deprivation, which also may cause follicular hyperkeratosis (Wiltshire, 1919). Moreover, vitamin A is usually administered in oily solution containing unsaturated 'essential' fatty acids (linoleic, arachidonic, linolenic) which also are claimed to be necessary for the maintenance of the normal skin (Hansen, 1937; Burr \& Barnes, 1943).

If vitamin A deficiency is the primary cause of follicular keratotic and other cutaneous conditions, like Darier's disease, pityriasis rubra pilaris, and ichthyosis, cure should be effected by administration of average doses of vitamin A. The fact that well over a hundred times the minimum daily dose of $125^{\circ}$ i.u. is needed, indicates that vitamin A deficiency cannot be the primary cause. The therapeutic effect conferred is not necessarily specifically nutritional; such doses may act by correcting hypochlorhydria (Földes \& Vajda, 194I), by influencing the allergic state (Obermeyer \& Frost, 1945), 
or by 'supercharging' (Leitner \& Moore, I $946 a$ ). In the last instance the excess of vitamin $A$ which cannot be retained and stored in the liver may appear in tissues from which it was excluded by the disease, where it may restore an equilibrium previously upset, and may control the regeneration of epithelial tissues.

Many other cutaneous conditions have been associated with vitamin A deficiency; such are phrynoderma (Nicholls, 1933), acne vulgaris (Straumfjord, 1943; Davidson \& Sobel, 1949), ichthyosis (Rapaport, Herman \& Lehman, 1942), leukoplakia vulvae (Hyams \& Bloom, I947) and pili torti (Siskind, 1947), and therapeutic successes have been reported.

Some recollections of our experiences with Darier's disease and with pityriasis rubra pilaris (Leitner, 1947 $a$; Leitner \& Moore, $1946 a, b, 1948$ ) may be of interest. Both diseases are characterized by hyperkeratosis in relation to the pilosebaceous glands and hair follicles, and the lesions are similar to those which were originally found in association with vitamin A deficiency (Frazier \& Hu, 193 I Loewenthal, 1933; Nicholls, 1933, 1934). Table 1 shows the mean plasma content of carotenoids and vitamin $A$ for

Table I. Mean values for carotenoids and vitamin $A$ in the plasma of 105 persons with common skin diseases

\begin{tabular}{lccc}
\multicolumn{1}{c}{ Disease group } & $\begin{array}{c}\text { No. of } \\
\text { cases }\end{array}$ & $\begin{array}{c}\text { Carotenoids } \\
\text { (i.u./100 ml.) }\end{array}$ & $\begin{array}{c}\text { Vitamin A } \\
\text { (i.u./100 ml.) }\end{array}$ \\
Eczemas & 26 & 109 & 126 \\
Pityriasis rosea & 5 & 119 & 92 \\
Psoriasis & 10 & 151 & 117 \\
Seborrhoea & 11 & 144 & 128 \\
Lupus vulgaris & 4 & 214 & 84 \\
Lichenifications & 13 & 139 & 123 \\
Acne vulgaris & 4 & 99 & 119 \\
Rosacea & 8 & 100 & 122 \\
Skin infections & 11 & 132 & 119 \\
Alopecia & 5 & 186 & 114 \\
Pruritus & 3 & 139 & 128 \\
Verruca & 1 & 84 & 101 \\
Urticaria pigmentosa & 1 & 55 & 78 \\
Erythema nodosum & 1 & 170 & 127 \\
Lymphogranuloma inguinale & 1 & 106 & 73 \\
Pityriasis lichenoides chronica & 1 & 104 & 284 \\
Mean for all cases & & 130 & 120
\end{tabular}

105 hospital cases suffering from a variety of skin diseases; Table 2 gives the same values for II6 healthy subjects and hospital patients suffering from conditions not likely to alter the vitamin A level. The figures are almost identical. Table 3 shows the values in nine cases of Darier's disease, 'Table 4 in eight cases of pityriasis rubra pilaris and Table 5 in seven cases of ichthyosis. It is quite evident that in all three conditions both the carotene and vitamin $A$ values are definitely below normal though, like others, we found in some cases quite normal levels (Peck, Chargin \& Sobotka, I94I; Peck, Glick, Sobotka \& Chargin, 1943; Carleton \& Steven, r943; Weiner \& Lewin, r943; Porter, Brunauer \& Godding, 1947). It may be said, however, that in our material, with a few exceptions, the initial vitamin $A$ values corresponded roughly to the degree of clinical involvement. The initial vitamin A values in our patients with 
Darier's disease were lower than in those with pityriasis rubra pilaris, but after dosing the highest vitamin A values were much higher and more quickly attained in Darier's disease than in pityriasis rubra pilaris. A constant high vitamin A level is, however, no guarantee of the success of treatment. For example, case no. 5 of Darier's disease

Table 2.! Mean values for carotenoids and vitamin $A$ in the plasma of 116 healthy subjects and hospital patients with diseases unlikely to affect the plasma value for vitamin $A$

$\begin{array}{lccc}\quad \begin{array}{c}\text { Group } \\ \text { cases }\end{array} & \begin{array}{c}\text { Carotenoids } \\ \text { (i.u./100 ml.) }\end{array} & \begin{array}{c}\text { Vitamin A } \\ \text { (i.u./100 ml.) }\end{array} \\ \text { 'Normal' } & 41 & 161 & 118 \\ \text { Accidents } & 4 & 141 & 78 \\ \text { Fractures } & 12 & 102 & 92 \\ \text { Arthritis } & 18 & 145 & 114 \\ \text { Varicose veins } & 19 & 110 & 123 \\ \text { Hernias } & 18 & 133 & 110 \\ \text { Haemorthoids } & 4 & 139 & 117 \\ \text { Mean for all cases } & & 139 & 113\end{array}$

Table 3. Mean values for carotenoids before dosing with vitamin $A$, and of vitamin $A$ before and after dosing with vitamin $A$, in the plasma of nine patients with Darier's disease (keratosis follicularis)

\begin{tabular}{|c|c|c|c|c|c|c|c|}
\hline \multirow[b]{3}{*}{$\begin{array}{c}\text { Case } \\
\text { no. }\end{array}$} & \multirow[b]{3}{*}{$\begin{array}{c}\text { Age } \\
\text { (years) }\end{array}$} & \multirow[b]{3}{*}{ Sex } & & & \multicolumn{3}{|c|}{ Vitamin $A$} \\
\hline & & & \multicolumn{2}{|c|}{ Carotenoids, before dosing } & \multicolumn{2}{|c|}{ Before dosing } & \multirow{2}{*}{$\begin{array}{l}\text { After dosing } \\
\text { Highest value } \\
\text { (i.u. } / 100 \mathrm{ml} \text {.) }\end{array}$} \\
\hline & & & $\begin{array}{l}\text { Mean value } \\
\text { (i.u. } / 100 \mathrm{ml} \text { ) }\end{array}$ & $\begin{array}{l}\text { Lowest value } \\
\text { (i.u./100 ml.) }\end{array}$ & $\begin{array}{l}\text { Mean value } \\
\text { (i.u./ } 00 \mathrm{ml} \text {.) }\end{array}$ & $\begin{array}{l}\text { Lowest value } \\
\text { (i.u./100 ml.) }\end{array}$ & \\
\hline $\mathbf{I}$ & 13 & M. & 102 & 100 & 78 & 55 & 1276 \\
\hline 2 & 33 & F. & I7I & 59 & 92 & 55 & 268 \\
\hline 3 & 61 & F. & 215 & 199 & 57 & 20 & 687 \\
\hline 4 & 31 & M. & 90 & 57 & 57 & 7 & 790 \\
\hline 5 & 53 & F. & 62 & 61 & 55 & 28 & 1846 \\
\hline 6 & 19 & F. & 113 & 95 & 106 & 103 & 278 \\
\hline 7 & 20 & F. & 45 & 37 & 70 & 45 & - \\
\hline 8 & $5^{2}$ & M. & 94 & 85 & I3I & 116 & - \\
\hline 9 & 34 & F. & 153 & I 53 & 66 & 66 & - \\
\hline \multicolumn{2}{|c|}{ Mean } & & 116 & 94 & 79 & 55 & 857 \\
\hline
\end{tabular}

(Table 3) had very high values for many years, but the improvement of the skin condition was slight. Case no. 8 of pityriasis rubra pilaris (Table 4 ) never attained vitamin A values above 227 i.u./100 ml., but the very serious condition healed clinically after 4 months' treatment (Barber \& Leitner, I95I). We are still of the same opinion as before that 'this does not imply that these conditions are solely due to any A-avitaminosis nor that vitamin A can cure these diseases' (Leitner, 1945).

Relation of vitamin $A$ to hepatic diseases. Since Moore (1929) first demonstrated that rats fed on carotene stored vitamin $A$ in the liver, it has been repeatedly shown that liver diseases may interfere with vitamin A metabolism, but keratomalacia (Thompson, I 894) and xerosis (Bloch, 1924a,b) were described much earlier in jaundiced children. In liver diseases not only does the absorption of vitamin A appear to be impaired (Breese \& McCoord, 1940) but its release from the liver is disturbed also (Meyer, Steigman, Popper \& Walter, 1943; Popper, Steigman, Meyer \& Zevin, 1943). Though 
about $95 \%$ of the vitamin A stored is stored in the liver (Moore, 1931), the vitamin A level in the plasma in infective hepatitis is low in spite of adequate liver stores (Harris \& Moore, 1947). In long-standing and extensive liver lesions, as in liver cirrhosis, not only the liver reserves (Wolf, 1932; Moore, 1937), but also the plasma vitamin A levels, are reduced (Haig \& Patek, I942). Vitamin A tolerance curves indicate that the level of

Table 4. Mean values for carotenoids before dosing with vitamin $A$, and for vitamin $A$ before and after dosing with vitamin $A$, in the plasma of eight patients with pityriasis rubra pilaris

\begin{tabular}{|c|c|c|c|c|c|c|c|}
\hline \multirow[b]{3}{*}{$\begin{array}{l}\text { Case } \\
\text { no. }\end{array}$} & \multirow[b]{3}{*}{$\begin{array}{c}\text { Age } \\
\text { (years) }\end{array}$} & \multirow[b]{3}{*}{ Sex } & \multirow{2}{*}{\multicolumn{2}{|c|}{ Carotenoids, before dosing }} & \multicolumn{3}{|c|}{ Vitamin A } \\
\hline & & & & & \multicolumn{2}{|c|}{ Before dosing } & \multirow{2}{*}{$\begin{array}{l}\text { After dosing } \\
\text { Highest value } \\
\text { (i.u./roo ml.) }\end{array}$} \\
\hline & & & \multicolumn{2}{|c|}{$\begin{array}{l}\text { Mean value Lowest value } \\
\text { (i.u./100 ml.) (i.u./100 ml.) }\end{array}$} & $\begin{array}{l}\text { Mean value } \\
\text { (i.u. } / 100 \mathrm{ml} \text {.) }\end{array}$ & $\begin{array}{l}\text { Lowest value } \\
\text { (i.u./100 ml.) }\end{array}$ & \\
\hline I & 14 & M. & $4 \mathrm{I}$ & $3^{I}$ & 48 & 46 & 408 \\
\hline 2 & $4 I$ & F. & $\begin{array}{r}758 \\
15\end{array}$ & I10 & 145 & 66 & 690 \\
\hline 3 & 2.5 & F. & 43 & 42 & 44 & 35 & 140 \\
\hline 4 & $46^{\circ}$ & M. & 93 & 28 & 90 & 80 & - \\
\hline 5 & 12 & $\mathrm{~F}$. & 200 & 200 & 140 & 85 & - \\
\hline 6 & 51 & M. & 105 & 102 & 97 & 80 & - \\
\hline 7 & 21 & F. & 151 & 93 & 96 & 70 & 255 \\
\hline 8 & 63 & M. & 85 & 84 & 34 & 32 & 227 \\
\hline \multicolumn{2}{|c|}{ Mean } & & 109 & 86 & 86 & $6 r$ & 344 \\
\hline
\end{tabular}

Table 5. Mean values for carotenoids, and for vitamin $A$, in the plasma of seven patients with ichthyosis, before dosing with vitamin $A$

\begin{tabular}{|c|c|c|c|c|c|c|}
\hline \multirow[b]{2}{*}{$\begin{array}{c}\text { Case } \\
\text { no. }\end{array}$} & \multirow[b]{2}{*}{$\begin{array}{c}\text { Age } \\
\text { (years) }\end{array}$} & \multirow[b]{2}{*}{ Sex } & \multicolumn{2}{|c|}{ Carotenoids } & \multicolumn{2}{|c|}{ Vitamin A } \\
\hline & & & $\begin{array}{c}\text { Mean value } \\
\text { (i.u./100 ml.) }\end{array}$ & $\begin{array}{l}\text { Lowest value } \\
\text { (i.u./roo ml.) }\end{array}$ & $\begin{array}{l}\text { Mean value } \\
\text { (i.u./roo ml.) }\end{array}$ & $\begin{array}{l}\text { Lowest value } \\
\text { (i.u./100 ml.) }\end{array}$ \\
\hline $\mathbf{I}$ & 28 & M. & 98 & 77 & 86 & 80 \\
\hline 2 & 13 & $F$ & 72 & 65 & 72 & 49 \\
\hline 3 & 32 & $F$ & 145 & 145 & 55 & 55 \\
\hline 4 & 30 & F. & 61 & $6 x$ & 50 & 50 \\
\hline 5 & 8 & F. & 33 & 33 & 19 & 19 \\
\hline 6 & $3 I$ & M. & 178 & 169 & 114 & 104 \\
\hline 7 & 40 & M. & II5 & 112 & 115 & 114 \\
\hline \multicolumn{2}{|c|}{ Mean } & & 100 & 94 & 73 & 67 \\
\hline
\end{tabular}

vitamin A in the blood is related to the degree of liver damage (Ralli, Papper, Paley \& Bauman, I94I ; Popper, Steigman, Meyer \& Zevin, I943; Popper, Steigman \& Zevin, 1943). There seems also to be a rough parallelism between the extent of the liver damage, as indicated by the hippuric-acid tolerance test, and the magnitude of the vitamin A values in the blood (Harris \& Moore, 1947). This may explain why, in Darier's disease and pityriasis rubra pilaris, we found in some cases severe impairment of liver function particularly when we were using the hippuric-acid test (Leitner, r947 $a$; Leitner \& Moore, 1946b, 1948), whereas Porter \& Brunauer (1949), using mainly other liver function tests, could find only minor abnormalities.

The urinary excretion of vitamin A in kidney and other diseases may be connected with the inability of the damaged liver to store the vitamin. 
Relation of vitamin A to febrile states. Paediatricians were, for many years, aware of the fact that very low plasma vitamin A levels were recorded in febrile diseases, especially in pneumonia (Lindqvist, 1937; Clausen \& McCoord, 1938). Analysing the livers of children who had died of pneumonia, Lindqvist (1938) found adequate liver stores, although the vitamin A level in the blood had been found very low a few days previously. In convalescence after feverish diseases vitamin A levels much higher than before the onset of the disease have repeatedly been recorded (Josephs, 1943; Steigman, Meyer \& Popper, 1945; Harris \& Moore, 1947).

The question arises whether the infective process, as such, or the elevation of the body temperature was responsible. In ninety-two patients at the Chicago Intensive Treatment Centre, where syphilis and gonorrhoea are treated by physically induced hyperthermia combined with chemotherapy, elevation of body temperature (rectal) up to rog. $5^{\circ}$ or $106^{\circ} \mathrm{F}$. was followed by depression of the plasma content of vitamin $\mathrm{A}$ and of carotene. The diminution of both values was directly related to the duration of fever, being about $10 \%$ after $3 \mathrm{hr}$. of fever, $20 \%$ after 6 , and $30 \%$ after 8 . On the 2 nd morning after the fever treatment a definite rise in the plasma value for vitamin $A$ was recorded, and on the $3^{\text {rd }}$ morning it returned to the original level without any medication or dietary supplements (Aron, Craig, Farmer, Kendell \& Schwemlein, 1946). In acute rheumatism a considerable and persistent fall of the vitamin $A$ level was found, the degree varying directly with the intensity of the rheumatic attack (Shank, Coburn, Moore \& Hoagland, 1944).

We approached the question on a somewhat wider basis (Jacobs, Leitner, Moore \& Sharman, 1951). Our material consisted of over 300 patients in hospital, including I 8 suffering from rheumatic fever, about another hundred with various pyrexial diseases such as pneumonia, pleurisy and tonsillitis, and about hundred more with miscellaneous illnesses. The number of male and female patients was equal. The age of the rheumatic subjects ranged from 5 to 60 years, with an average of 20.5 years, $64 \%$ of the patients being between 5 and 19 years. The other groups included fewer children and more middle-aged subjects. The vitamin A values were lower with increasing body temperature to about the same extent in rheumatic fever, pneumonia, pleurisy, tonsillitis and erythema nodosum. The inverse relation was not, however, absolutely constant.

The claim has recently been advanced that there is a sudden and considerable increase of the circulating plasma volume in rheumatic fever (Reid, Watson \& Sproull, 1950). Bradley (1951) attributes the sudden anaemia and heart failure in the acute rheumatic attack to the accompanying decrease in haemoconcentration. This aspect is very interesting, but it is difficult to correlate our results as yet with the very few estimations of blood volume in rheumatic fever published so far. It appears also that the fall of the vitamin A level in our patients was not in proportion to the blood dilution, and it was greater than in experimentally produced fever. In the present state of our experience I am, therefore, inclined to attribute the fall in plasma vitamin A level to disturbances in vitamin A metabolism. The derangement might differ little at first in the different pyrexial states, but in rheumatic fever additional factors come into play, such as the prolonged course of the illness and the frequent relapses at an age when the normal requirements for growth and development are greatest. The end effect of 
Z. A. LEITNer. Pathology of vitamin a deficiency and its clinical Plate $\mathbf{I}$ SIGNIFICANCE

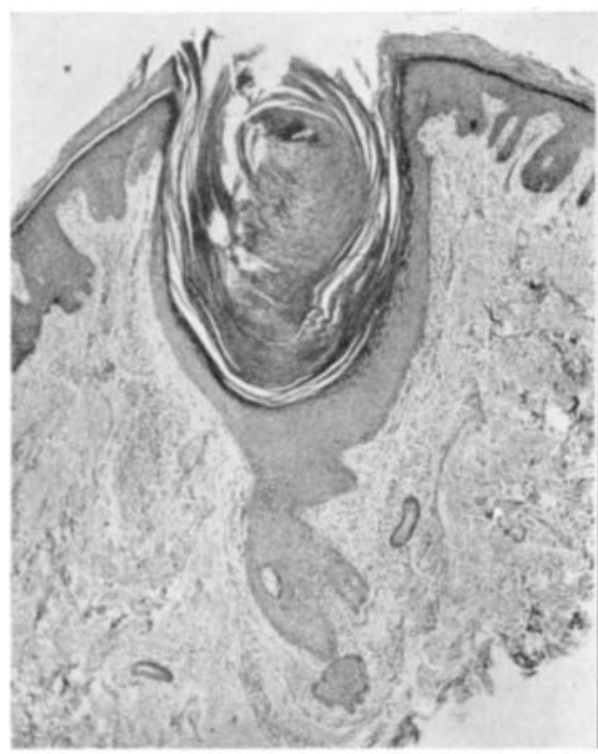

I

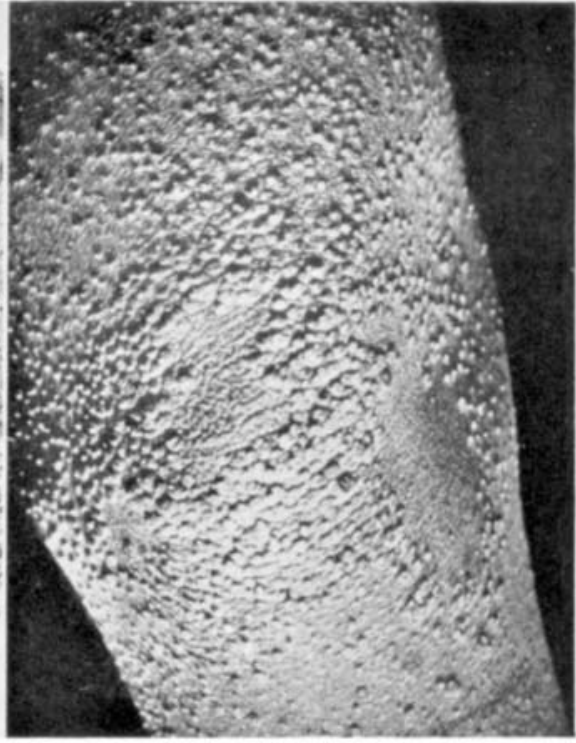

2

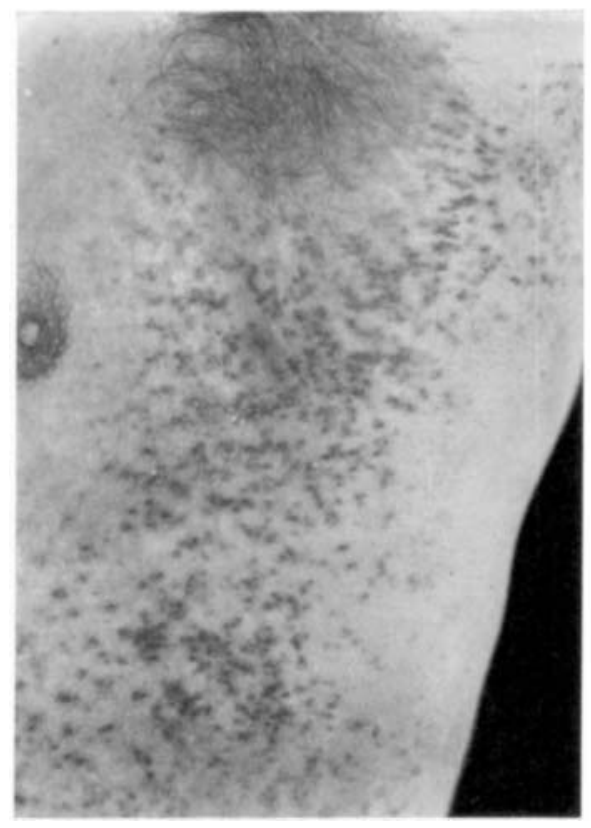

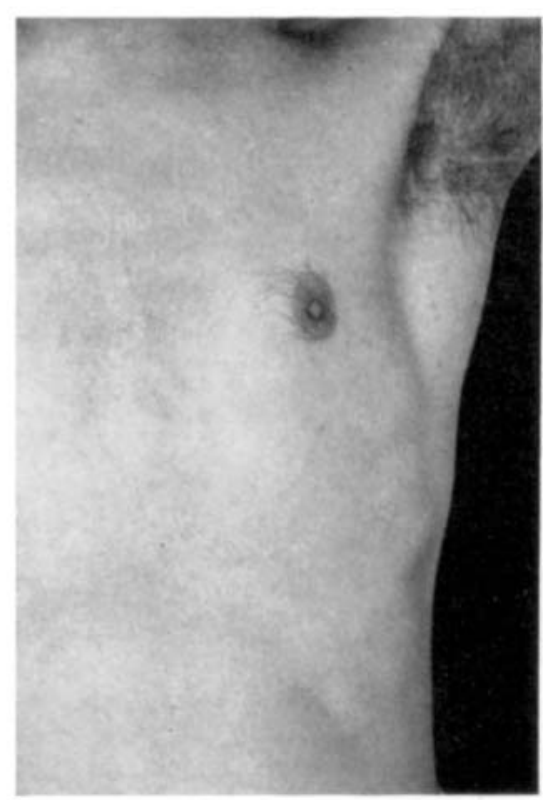

British Yournal of Nutrition, Vol. 5, No. I 
Z. A. Leitner. Pathology of vitamin A deficiency and its clinical Plate 2 SIGNIFICANCE

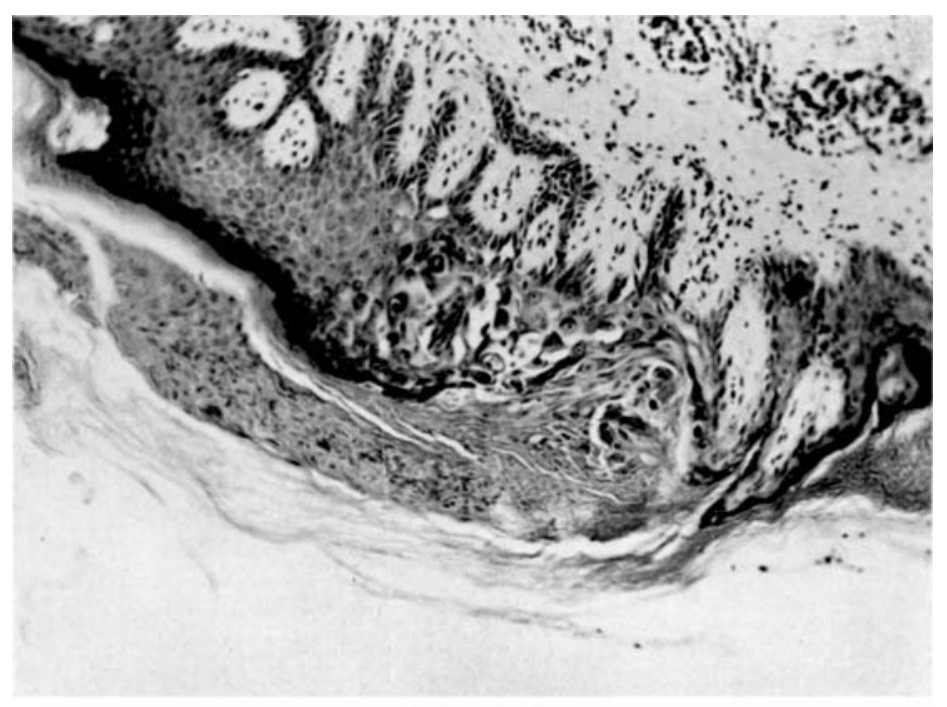

$\mathbf{I}$

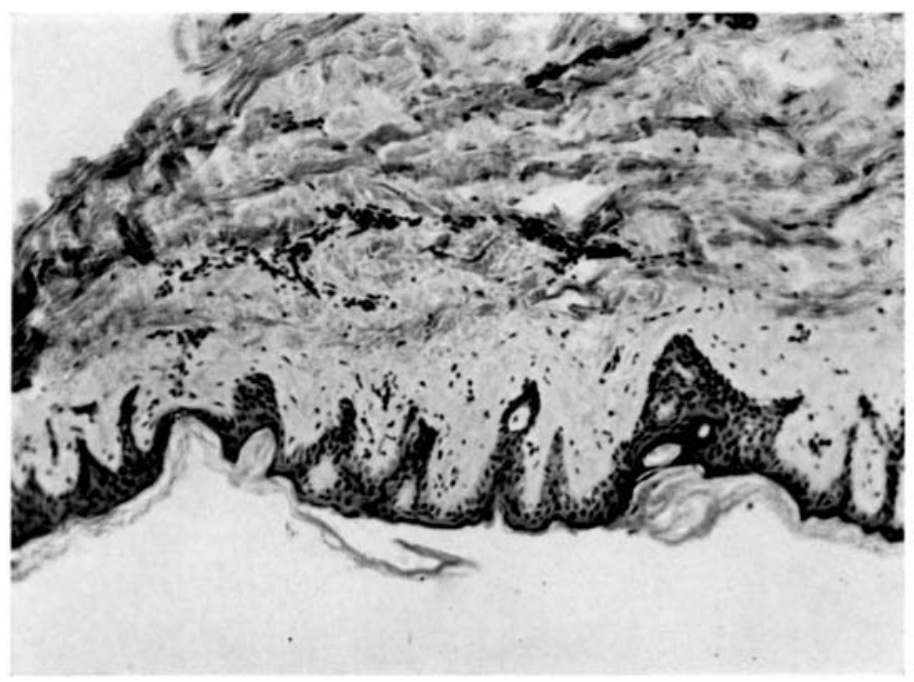


vitamin A depletion in acute rheumatism may, therefore, appear to be different and more complex. In previous preliminary experiments on rheumatic patients, I had the impression that besides a nutritious diet, a daily supplement of 40,000-50,000 i.u. vitamin A was beneficial (Thornton, 1946).

In conclusion, there are two conditions in which I should like to make a suggestion that seems justified by the present state of vitamin A research, though the therapeutic necessity cannot yet be fully substantiated. I would like to advocate that a daily dose of 40,000-50,000 i.u. vitamin A be given in rheumatic fever, and in pregnancy complicated by febrile states, especially during the first trimester, which corresponds mainly to the organogenic period. Future research may support and possibly widen the range of these, as yet tentative, suggestions.

\section{SUMMARY}

I. After a short survey of the principal tissue changes, the results of experimentally produced congenital abnormalities related to vitamin A deficiency have been presented. The possible relationship of vitamin A deficiency to two inherited diseases in man, fibro-cystic disease of the pancreas and pityriasis rubra pilaris, has been discussed.

2. The importance of environmental factors in the manifestation of a latent hereditary trait has been emphasized. It has been suggested on the basis of experimental results that the frequency of a congenital malformation may be enhanced by deficiencies in the diet during pregnancy and, further, that neonatal mortality and the incidence of congenital malformations in man may increase under unfavourable nutritional circumstances.

3. The clinical significance of vitamin A deficiency has been referred to in relation to the ocular system (hemeralopia, Bitot's spots, xerophthalmia, keratomalacia), and has been discussed at greater length in relation to certain cutaneous diseases (Darier's disease, pityriasis rubra pilaris), to involvement of the liver, and to febrile states.

4. The suggestion has been put forward, that it might prove advantageous to give 40,000-50,000 i.u. vitamin A daily in rheumatic fever, and in pregnancy complicated by febrile states, especially during the first trimester.

\section{EXPLANATION OF PLATES}

\section{Plate I}

1. Gland duct filled with keratotic plugs.

2. Gross follicular hyperkeratosis in vitamin A deficiency.

3. Darier's disease before vitamin A treatment.

4. Darier's disease after vitamin A treatment.

Plate 2

I. Microscopic changes in Darier's disease before vitamin A treatment.

2. Microscopic changes in Darier's disease after vitamin A treatment.

\section{REFERENCES}

Andersen, D. H. (1938). Amer. F. Dis. Child. 56, 344.

Andersen, D. H. (1949a). Proc. R. Soc. Med. 42, 25.

Andersen, D. H. (1949b). Amer. F. Path. 25, 163.

Andersen, D. H. (1949c). Pediatrics, 3, 406 .

Andersen, D. H. \& Hodges, R. G. (1946). Amer. F. Dis. Child. 72, 62. 
Aron, H. C. S., Craig, R. M., Farmer, C. J., Kendell, H. W. \& Schwemlein, G. X. (1946). Proc. Soc. exp. Biol., N.Y., 61, 271.

Aykroyd, W. R. (1930). F. Hyg., Camb., 30, 357.

Barber, H. W. \& Leitner, Z. A. (195I). In preparation.

Barber, H. W. \& Tatz, K. (1946). Proc. R. Soc. Med. 39, 223.

Beattie, J. M., Dickson, W. D. C. \& Drennan, A. M. (r948). Textbook of Pathology, General and Special, $5^{\text {th }}$ ed., p. 303. London: Wm. Heinemann.

Bitot, C. (1863). Gaz. hebd. Méd. Chir. 10, 284.

Blackfan, K. D. \& May, C. D. (1938). I. Pediat. 13, 627.

Blackfan, K. D. \& Wolbach, S. B. (1933). Y. Pediat. 3, 679.

Bloch, C. E. (1924a). Amer. F. Dis. Child. 27, 139.

Bloch, C. E. (1924b). Amer. F. Dis. Child, 28, 659.

Bodian, M. (1 950). Personal communication.

Bonfils, S. (1947). Bull. Soc. méd. Hôp. Paris, 63, 1093.

Boyle, P. E. (1933). F. dent. Res. 13, 39.

Bradley, W. H. (195I). Proc. R. Soc. Med. (In the Press.)

Breese, B. B. \& McCoord, A. B. (1940). F. Pediat. 16, 139.

Burr, G. O. \& Barnes, R. H. (1943). Physiol. Rev. 23, 256.

Carleton, A. \& Steven, D. (1943). Arch. Derm. Syph., N.Y., 48, 143.

Clausen, S. W. \& McCoord, A. B. (1938). F. Pediat. 13, 635.

Cockayne, E. A. (1947). In Garrod, Batten and Thursfield's Diseases of Children, Vol. I, p. 6. London: Amold.

Cockayne, E. A. (1950). Personal communication.

Cornbleet, T. \& Popper, H. (1942). Arch. Derm. Syph., N.Y., 46, 59.

Davidson, D. M. \& Sobel, A. E. (1949). F. Invest. Derm. 12, 221.

de Haas, J. H. \& Meulemans, O. (1938). Lancet, 234, I I Io.

Farber, S. (1944). F. Pediat. 24, 387.

Fasold, H. \& Peters, H. (1933). Z. ges. exp. Med. 92, 57.

Fletcher, D. E. \& Rigdon, R. H. (1 949). Arch. Neurol. Psychiat., Chicago, 61, 199.

Földes, F. \& Vajda, G. (1941). Brit. med. F. i, 317.

Frazier, C. N. \& Hu, C. K. (1931). Arch. intern. Med. 48, 507.

Fridericia, L. S. \& Holm, E. (1925). Amer. F. Physiol. 73, 63.

Haig, C. \& Patek, A. J. Jr. (1942). F. clin. Invest. 21, 309.

Hale, F. (1933). F. Hered. 24, 105.

Hale, F. (1935). Amer. F. Ophthal. 18, 1087.

Hale, F. (1937). Tex. St. F. Med. 33, 228.

Hansen, A. E. (r937). Amer. F. Dis. Child. 53, 933.

Harris, A. D. \& Moore, T. (1947). Brit. med. F. i, 553.

Hume, E. M. \& Krebs, H. A. (1949). Spec. Rep. Ser. med. Res. Coun., Lond., no. 264.

Hyams, M. N. \& Bloom, O. H. (1947). Amer. F. Obstet. Gynec. 53, 214.

Irving, J. J. \& Richards, M. B. (1940). Biochem. F. 34, 198.

Jackson, B. \& Kinsey, V. E. (1946). Amer. F. Ophthal. 29, 1234.

Jacobs, A. L., Leitner, Z. A., Moore, T. \& Sharman, I. M. (195I). In preparation.

Josephs, H. W. (1943). Amer. F. Dis. Child. 65, 712.

King, J. D. (1940). Brit. dent. F. 68, 349.

Lafontaine, A. (1948). Sang, r9, 107.

Leitner, Z. A. (1945), Proc. R. Soc. Med. 38, 34r.

Leitner, Z. A. (1946). Proc. R. Soc. Med. 39, 224.

Leitner, Z. A. (1947a). Brit. F. Derm. Syph. 59, 407.

Leitner, Z. A. (1947b). Proc. R. Soc. Med. 4I, 326.

Leitner, Z. A. (1948). Brit. med. Y. i, 917.

Leitner, Z. A. \& Ford, E. B. (1947). Brit. F. Derm. Syph. 59, 424.

Leitner, Z. A. \& Moore, T. (1946a). Lancet, 251, 262.

Leitner, Z. A. \& Moore, T. (1946b). Brit. F. Derm. Syph. 58, I I.

Leitner, Z. A. \& Moore, T. (1948). Brit. F. Derm. Syph. 60, 41.

Leitner, Z. A., Moore, T. \& Sharman, I. M. (1947). Brit. $\mathcal{~}$. Nutrit. r, v.

Lindquist, 'T. (1937). Klin. Wschr. 16, I345.

Lindquist, T. (1938). Acta med. scand., Suppl. no. 97.

Locwenthal, L. J. A. (1933). Arch. Derm. Syph., N.Y., 28, 700.

McCullough, K. \& Dalldorf, G. (1937). Arch. Path. 24, 486.

Marrack, J. R. (1948). Modern Trends of Dermatology, p. 72. London: Butterworth.

Mattheson, W. J. (1949). Brit. med. F. ii, 206.

Mellanby, E. (1931). Brain, 54, 247. 
Mellanby, E. (1935). Brain, 58, 141.

Mellanby, E. (1938). F. Physiol. 94, 380.

Mellanby, E. (1939a). J. Physiol. 96, xxoxvi.

Mellanby, E. (1939b. Int. Congr. Neurol. III. Copenhagen, p. 797.

Mellanby, E. (1941). F. Physiol. 99, 467.

Mellanby, E. (1943a). F. Physiol. 101, 408.

Mellanby, E. (1943b). Proc. R. Soc. Med. 36, 621 .

Mellanby, E. (1947). F. Physiol. r05, 382.

Mellanby, H. (1939). Brit. dent. F. 67, 187.

Métivier, V. M. (194I). Amer. F. Ophthal. 24, 1029.

Meyer, K. A., Steigman, T., Popper, H. \& Walter, W. H. (1943). Arch. Surg., Chicago, 47, 26.

Moore, L. A. (1939). F. Nutrit. 17, 443.

Moore, L. A. \& Sykes, J. F. (1940). Amer. F. Physiol. x30, 684.

Moore, T. (1929). Lancet, 217, 380.

Moore, T. (1930). Biochem. F. 24, 696.

Moore, T. (1931). Biochem. F. 25, 275.

Moore, T. (I 937 ). Biochem. F. 3I, I 55.

Moore, T. (1946). Brit. F. Derm. Syph. 58, 17.

Moore, T. \& Leitner, Z. A. (1949). Spec. Rep. Ser. med. Res. Coun., Lond., no. 264, p. 65.

Mori, M. (1904). Fb. Kinderheilk. 59, 175.

Morton, R. A. \& Ball, S. (1949). Biochem. F. 45, 298.

Moult, F. H. (1943). Arch. Derm. Syph., N.Y., 47, 768.

Nicholls, L. (1933). Indian med. Gaz. 68, 681.

Nicholls, I. (1934). Indian med. Gaz. 69, 241.

Nicholls, L. \& Nimalasuriya, A. (1939). Lancet, 236, 1432.

Obermeyer, M. E. \& Frost, K. (1945). Arch. Derm. Syph., N.Y., 51, 309.

Owens, W. C. \& Owens, U. (1949). Amer. F. Ophthal. 32, 1631.

Parmelee, A. H. (1935). Amer. F. Dis. Child. 50, 1418.

Peck, S. M., Chargin, L. \& Sobotka, H. H. (I941). Arch. Derm. Syph., N.Y., 43, 223.

Peck, S. M., Glick, A. W., Sobotka, H. H. \& Chargin, L. (1943). Arch. Derm. Syph., N.Y., $48,17$.

Pillat, A. (1929). Chin. med. F. 43, 907.

Pillat, A. (1930). Arch. Ophthal. 124, 486.

Popper, H. (1941). Arch. Path. 31, 766.

Popper, H., Steigman, F., Meyer, K. A. \& Zevin, S. S. (1943). Arch. intern. Med. 72, 439.

Popper, H., Steigman, F. \& Zevin, S. (1943). F. clin. Invest. 22, 775.

Porter, A. \& Brunauer, S. R. (1949). Brit. F. Derm. Syph. 6r, 277.

Porter, A., Brunauer, S. R. \& Godding, E. W. (1947). Arch. Derm. Syph., N.Y., 56, 306.

Ralli, E. P., Papper, E., Paley, K. \& Bauman, E. (1941). Arch. intern. Med. 68, 102.

Rao, M. V. R. (1940). Indian Y. med. Res. 27, 731 .

Rapaport, H. G., Herman, H. \& Lehman, E. (1942). F. Pediat. 21, 733.

Reid, J., Watson, R. D. \& Sproull, D. H. (1950). Quart. F. Med. 19, I.

Sadhu, D. P. (1948). Amer. F. Physiol. 152, 263.

Shank, R. E., Coburn, A. F., Moore, L. V. \& Hoagland, C. L. (1944). F. clin. Invest. $23,289$.

Simkins, S. ( 1947). F. clin. Endocrinol. 7, 574.

Siskind, W. M. (r947). Arch. Derm. Syph., N.Y., 56, 540.

Stannus, H. S. (1945). Proc. R. Soc. Med. 38, 337.

Steffens, L. F., Bair, H. L. \& Sheard, C. (1939). Proc. Mayo Clin. 14, 698.

Steigman, F., Meyer, K. A. \& Popper, H. (1945). Ann. intern. Med. 22, 832.

Straumfjord, J. V. (1943). Nordwest. Med. 42, 2 I9.

Sullivan, M. \& Evans, V. J. (1945). Arch. Derm. Syph., N.Y., 5r, I7.

Sweet, L. K. \& K'ang, H. J. (1935). Amer. Y. Dis. Child. 50, 699.

Thompson, J. T. (1894). Brit. med. F. ii, 597.

Thornton, C. E. (1946). Rep. med. Offr Hlth, Lond. Co. Coun., p. 77.

Togby, A. F. (1935). Bull. Soc. Ophthal., Egypte, 28, 79.

Touraine, A. (1942). Bull. Soc. franf. Derm. Syph. 49, 175.

Wald, G. (1936). F. gen. Physiol. 20, 45.

Warkany, J. (1948). Obstet. Gynec. Surv. 3, 693.

Warkany, J. \& Roth, C. B. (1948). F. Nutrit. 35, 1.

Warkany, J. \& Schraffenberger, E. (1944). Proc. Soc. exp. Biol., N. Y., 57, 49.

Warkany, J. \& Schraffenberger, E. (1946). Arch. Ophthal. 35, I 50.

Weiner, A. L. \& Lewin, A. A. (1943). Arch. Derm. Syph., N.Y., 48, 288.

Williamson-Noble, F. A. (1942). Trans. ophthal. Soc. U.K. 62, 53.

Wilson, J. G. \& Barch, S. (1949). Proc. Soc. exp. Biol., N.Y., 72, 687. 
Wilson, J. G. \& Warkany, J. (1947). Proc. Soc. exp. Biol., N. Y., 64, 419.

Wilson, J. G. \& Warkany, J. (1948). Amer. F. Anat. 83, 357.

Wilson, J. G. \& Warkany, J. (1949). Amer. F. Anat. 85, 113.

Wilson, J. G. \& Warkany, J. (1950). Pediatrics, 5, 708.

Wiltshire, H. (1919). Lancet, 197, 564 .

Wolbach, S. B. \& Bessey, O. A. (1940). Science, 91, 599.

Wolbach, S. B. \& Bessey, O. A. (1941). Arch. Path. 32, 689.

Wolbach, S. B. \& Bessey, O. A. (1942). Physiol Rev. 22, 233.

Wolbach, S. B. \& Howe, P. R. (1925). F. exp. Med. 43, 753 .

Wolbach, S. B. \& Howe, P. R. (1926). Arch. Path. 1, I.

Wolbach, S. B. \& Howe, P. R. (1933a). F. exp. Med. 57, 511 .

Wolbach, S. B. \& Howe, P. R. (1933b). Amer. F. Path. 9, 275.

Wolf, I. K. (1932). Lancet, 223, 6 I 7 .

\title{
SIXTY-THIRD SCIENTIFIC MEETING-TWENTY-NINTH SCOTTISH MEETING
}

USHER INSTITUTE, EDINBURGH

14 OCTOBER $195^{\circ}$

\section{GROWTH}

\author{
Chairman: Professor F. A. E. CREW, F.R.S., Usher Institute of \\ Public Health, Edinburgh
}

\section{Growth and Health}

\section{By I. LeItch, Commonwealth Bureau of Animal Nutrition, Bucksburn, Aberdeenshire}

A general introduction to a discussion on growth and health might take either of two main forms. It might review what we know about the material requirements for growth: the total energy needs, the grams of protein required to give this or that amount of soft tissue growth, the grams of calcium and phosphorus required for growth of the skeleton; it might discuss the functional importance of substances that make little material contribution to growth, and finally, sum up what we know about the interrelation of diet and resistance to infection. These are the subjects with the details of which most of the observational and experimental work in nutrition is, at the moment, concerned. It would take days to sum up the information; and, when that had been done, I doubt whether we should be able to do more than reaffirm general principles. 'These general principles are already well known. The concept of a balanced diet has become part of our 'common knowledge'.

Perhaps partly because I shirked that major task, and partly because I think it is good, now and then, to lay aside the microscope and look at things with the naked eye, I have chosen the second approach. In very general terms I am going to ask what we mean by good growth and by health and what the one has to do with the other.

In experimental work with animals most often weight increase is taken as if it were synonymous with growth; less often growth is defined as increase in one or more linear dimensions. Obviously increase in weight may be increase in bone or muscle or fat 